\title{
Evaluation of Maize (Zea mays L.) Varieties for Moisture Stress Areas
}

\author{
Gobeze Loha $^{1} \quad$ Abebe Endale $^{1} \quad$ Rahel Tigabu $^{2} \quad$ Abdishikur Reshid $^{1} \quad$ Zemach Sorsa $^{1}$ \\ 1.Wolaita Sodo University, Department of Plant Sciences, Sodo, Ethiopia \\ 2.Medawolabu University, Department of Plant Sciences, Goba, Ethiopia
}

\begin{abstract}
Maize is priority crop to farmers because it is a stable food in many rural communities of southern region. It is widely grown in the various parts of southern region from lowland to mid-highlands. On other hand, moisture stress is one the most critical production constraints of maize in low to intermediate agro-ecology. Thus, developing maize varieties tolerant to moisture is of paramount important in order to sustain maize production in moisture areas. In this content, field experiments were conducted during 201617 cropping at Kindo Koyisha and Humbo with objective to select adaptable maize varieties for moisture stress with reasonable grain yield. Treatments used in this study were eight maize varieties (BH546, BH547, Gibe II, MH130, Melkasa IV, MH140, Melkasa II and Melkasa 6Q) and three local cultivars (Local red, Local mixed and Local white) of total of eleven maize genotypes were evaluated at two moisture prone areas in southern Ethiopia. Treatments were laid out in a randomized complete block design (RCBD) with three replications. Maize varieties exhibited difference performance at two tested locations. Varieties had relatively superiority of performance Kindo Koyisha as compared to Humbo. At Humbo varieties MH140, MH130 BH546 and Melkasa IV gave relatively higher grain yield. At Kindo Koyisha maize varieties expressed relatively better performance with respect to grain yield. At this location varieties with superior performance with sounding grain yield were BH546, MH140, BH547 and MH130. Based on this result BH546, MH140 and MH130 could be used at both locations. Moreover, BH547 at Bale and Melkasa IV at Humbo also could used to respective locations for production.
\end{abstract}

Keywords: Maize varieties and moisture stress

DOI: $10.7176 / \mathrm{JBAH} / 11-17-03$

Publication date:September $30^{\text {th }} 2021$

\section{Introduction}

Maize (Zea mays L.) has become the third most important cereal crop in the world, because of its high adaptability and productivity (Mosisa et al., 2002). Globally maize is cultivated under diverse climatic conditions but yields best under moderate temperatures with sufficient water. However, on the African continent, it is the most important food crop and mainstay of rural diets in the eastern and southern regions (FAO, 2003; Maredia, et al., 2000; Pingali, \& Pandey, 2001). Maize has a higher carbohydrate production potential per unit land than other cereals and was the first major cereal to undergo rapid and widespread technological transformation in its cultivation (Palwal, 2000). In developed countries, maize is grown mainly for animal feed and as raw materials for industrial products, such as starch, glucose, and dextrose and bio fuel. Therefore, maize occupies an important position in Africa and on the global economy where it is traded as a food, feed and industrial grain crop (Vasal, 2000).

In Ethiopia, cereals account for about $82.34 \%$ of the annual national crop production. Maize ranks first in total production and yield per unit area and second in area coverage among all the cereals. It is largely produced in western, central, southern and eastern regions (CSA, 2010). Maize research has advanced from landraces to varieties, to maize hybrids: double cross, three-way cross and single cross, and recently transgenic maize hybrids. The optimized use of adapted and exotic germplasm in various production environments is a key to the continued success in increasing grain yield and other trait-specific products: green ear, forage, oil, protein, starch. Moreover, maize is priority crop to farmers because it is a stable food in many rural communities of southern region. It is widely grown in the various parts of southern region from lowland to mid-highlands. On other hand, moisture stress is one the most critical production constraints of maize in low to intermediate agro-ecology. However, the extent of yield reduction due to moisture stress varies with genotypes. Developing maize varieties tolerant to moisture is of paramount important in order to sustain maize production in moisture areas. Hence, the objective of this study was to select adaptable maize varieties for moisture stress with reasonable grain yield.

\section{MATERIALS AND METHODS}

\subsection{Experimental site}

Field experiments were conducted during 2016/17 cropping at Kindo Koyisha (Altitude 1170 masl, annual rainfall $924 \mathrm{~mm}, 2100$, major crops cultivated in the study area include maize, sorghum and sweet potato) and Humbo (Altitude 1800, annual rainfall 1295 with bimodal rainfall patterns, average temperature of $20^{\circ} \mathrm{c}$ ). 


\subsection{Treatments and experimental design}

Treatments used in this study were eight maize varieties (BH546, BH547, Gibe II, MH130, Melkasa IV, MH140, Melkasa II and Melkasa 6Q) and three local cultivars (Local red, Local mixed and Local white) of total of eleven maize genotypes were evaluated at two moisture prone areas in southern Ethiopia. Treatments were laid out in a randomized complete block design (RCBD) with three replications. The plot size was $4 \mathrm{x} 4 \mathrm{~m}$ with $1.5 \mathrm{~m}$ between replications and $1.0 \mathrm{~m}$ between plots. Planting was carried out as per planting time of respective area following the onset of rainfall. Maize was hand planted by placing two seeds per hill and thinned after emergence to maintain the proposed plant density per plot. Weed control was carried out by hand or hand hoeing, while diseases and insect damage were visually monitored during crop growing season. Phosphorus fertilizer in the form of DAP and $\mathrm{N}$ in the form urea were applied as per recommendation for maize production. Moreover, other crop management practices carried out as desired.

\subsection{Data collection and measurements}

Data recorded on yield components included ear length, ear diameter, number of seeds per row, kernels per ear, thousand seed weight and prolificacy (ears per plant). Ear length and diameter were measured for five randomly selected plants from the base to the tip and at approximately the middle of the ear at harvesting, respectively. Number of seeds per row was counted for five randomly selected plants. Seed number per ear was determined multiplying the number of rows by the number of seeds per row. Thousand seed weight (TSW) was measured by counting a thousand seeds with a seed counter and weighing it with sensitive balance. Prolificacy is the property of producing more ears per plant and estimated by dividing the number of ears by number of plants per plot. Grain was manually harvested from net plot and converted to $\mathrm{kg} / \mathrm{ha}$ after adjusting the moisture content to $12.5 \%$. Biomass yield was estimated as the sum of stover weighed and grain yield. Harvest index (HI) is the ratio of grain yield to the total biomass yield which was estimated by dividing grain yield by total biomass. Data were subjected to analysis of variance using the general linear model SAS version 9.1 (SAS Inst., 2003). Treatments means were compared using the least significant difference (LSD) at $5 \%$ probability level.

\section{Results}

\subsection{Plant and ear heights}

The data for plant and ear heights as affected by location and varieties are depicted in Table 1. Analysis o variance indicated that location had significant effect on plant and ear height. Both parameters were higher at Kindo Koyisha as compared to Humbo. Similarly, maize varieties were significantly differed for plant height and ear height. The tallest plant height $(235 \mathrm{~cm})$ was recorded for variety BH547 followed by variety BH547 with mean plant height of $229 \mathrm{~cm}$. The shortest plant height $(156 \mathrm{~cm})$ was seen for variety Melkasa 6Q. In line with this, the tallest ear heights $(117 \mathrm{~cm})$ was observed for BH547 followed by variety Local mixed with mean ear height of $58 \mathrm{~cm}$. On the other hand, location by variety interactions resulted in significant differences on ear heights (Table 1). Generally, all varieties exhibited taller ear heights at Kindo Koyisha as compared to Humbo. The tallest ear height $(148 \mathrm{~cm})$ was observed for variety Local white at Humbo followed by variety BH547 at Kindo Koyisha with mean ear height of $147 \mathrm{~cm}$. The shortest ear height $(34 \mathrm{~cm})$ was seen for variety Melkasa 6Q at Humbo. In contrast, location by varieties interaction did not have significant effect plant heights.

\subsection{Ear length and ear diameter}

The data for ear length and ear diameter as affected by location and varieties are presented in Table 2. Analysis of variance showed that main effect of location and varieties had significant differences on length. The ear length of maize varieties was higher at Kindo Koyisha than that of Humbo. Regarding varieties, averaged over locations, the longest cob length $(15.13 \mathrm{~cm})$ was obtained from variety BH546 followed by variety BH547 with mean ear length of $13.74 \mathrm{~cm}$. The shortest ear diameter $(11.62 \mathrm{~cm})$ was seen for variety Melkasa 6Q. In line with this, interaction of location by varieties resulted in significant differences on ear length (Table 2). The longest ear length $(15.83 \mathrm{~cm})$ was recorded for variety BH546 at Kindo Koyisha followed by variety BH547 with mean cob length of $14.45 \mathrm{~cm}$ at the same location. The shortest ear length $(9.69 \mathrm{~cm})$ was seen for local white at Humbo. On the other hand, only main effect of varieties exhibited significant differences on ear length. The longest cob diameter $(4.75 \mathrm{~cm})$ was measured for variety BH546 followed by variety BH547 with mean ear diameter of $4.34 \mathrm{~cm}$. the shortest ear diameter $(4.03 \mathrm{~cm})$ was observed for local white. However, main effect of location and its interactions with varieties did not have significant effect on ear diameter.

\subsection{Rows per ear, seeds per row, seeds per ear and thousand seed weight}

Number of rows per ear seeds per row, seeds per ear and TSW as affected by location and varieties are shown in Table 3. Analysis of variance indicated that the main effect of location had significant effect on number of seeds per row and seeds per ear. Both parameters were higher at Kindo Koyisha as compared to that of Humbo. Similarly, varieties exhibited significant differences number of rows per ear, seeds per row, seeds per ear and 
TSW (Table 3). Variety BH547 produced the highest number of per ear (15.1) followed by variety Melkasa 6Q with mean number of rows per ear of 14.8. The least number of rows per cob (12.4) was seen for Local white. In line with this, the greatest number of seeds per row (34) and seeds per cob (469) were recorded for variety BH546 followed by variety BH547 with mean number of seeds per row and seeds per ear of 30 and 445 , respectively. Local white yielded the lowest number of seeds per row (26) and seeds per ear (295). Moreover, location by variety interactions resulted in significant on number of seeds per row. The greatest number of seeds per row (36) was recorded that Kindo Koyisha for variety BH546 followed by the same location for variety BH547 with mean number of seeds per row of 34. The lowest number of seeds per row (22) was seen for Local white. In contrast, main effect of location, variety and their interactions did not have significant effect on TSW, seeds per row and rows per ear (Table 3 ).

\subsection{Biomass, grain yield and harvest index}

The data for biomass, grain yield and HI as affected by location and variety are depicted in Table 4. Location did not have significant effect on biomass yield of maize varieties. However, varieties exhibited significant differences on biomass yield. Biomass yield for maize varieties ranged from 7083 to $14792 \mathrm{~kg} / \mathrm{ha}$ with the highest biomass yield recorded (14792 kg/ha) for variety BH546 followed by variety BH547 with biomass yield of $14688 \mathrm{~kg} / \mathrm{ha}$. The lowest biomass yield $(7083 \mathrm{~kg} / \mathrm{ha})$ was obtained from variety Melkasa 6Q. In line with this, location by varieties interactions resulted in significant differences on biomass yield. The greatest biomass yield $(17188 \mathrm{~kg} / \mathrm{ha})$ was recorded at Kindo Koyisha for variety BH547 followed by variety BH546 at the same location with mean biomass yield of $15938 \mathrm{~kg} / \mathrm{ha}$. The lowest biomass yield $(6979 \mathrm{~kg} / \mathrm{ha})$ was seen for variety Melkasa 6Q at Kindo Koyisha.

Grain yield was significantly differed in response to location where higher grain yield was obtained from Kindo Koyisha as compared to Humbo (Table 3). Similarly, maize varieties exhibited significant differences on grain yield. The highest grain yield $(5208 \mathrm{~kg} / \mathrm{ha})$ was recorded at Kindo Koyisha for variety BH546 followed by MH140 with mean grain yield of $5000 \mathrm{~kg} / \mathrm{ha}$ at the same location. The lowest grain yield $(2396 \mathrm{~kg} / \mathrm{ha}) \mathrm{was}$ achieved from Local red at Humbo. In general maize varieties tested for moisture responded differently to respective environments. At Kindo Koyisha varieties BH546, MH140 and BH547 showed reasonable performance in a such moisture stress prone environment. On other hand, MH140 and MH130 relatively exhibited superiority over others at Humbo.

\section{Discussion}

Maize varieties exhibited differently for agronomic traits measured in response to location with respect of their genetic variability (Table 1, 2, 3 and 4). Generally almost all maize varieties showed superior performance at Kindo Koyisha as compared to Humbo for agronomic traits. The grain yield differences recorded was $730 \mathrm{~kg} / \mathrm{ha}$ between Kindo Koyisha and Humbo. Thus, relatively the performances of varieties were poor at Humbo which probably suggests that Kindo Koyisha was relatively better environment with plant growth conditions. Moreover, this illustrated that subjecting plants to favorable growing conditions increased the ability of varieties for capturing resources which was reflected as evident in their increased agronomic performance. The significant effects of environments indicated that the genotypes performed differently across locations. Thus, the mean yield of genotypes differed from location to location. Similarly, maize varieties, averaged over locations, showed significant differences on plant height, ear height, rows per cob, seeds per row, seeds per cob, ear length and ear diameter (Table 1, 2 and 3). Relatively higher plant height $(\geq 200 \mathrm{~cm})$ was recorded for varieties BH546, BH547 and MH140 whereas ear heights $(\geq 100 \mathrm{~cm})$ were recorded for varieties BH547, Local mixed and Local white. Variety BH546 gave the longest cob length while BH547 produced the highest cob diameter. Variety BH547 gave the highest number of rows per cob while variety BH547 produced the greatest number of seeds per row and seeds per cob. Maize varieties, averaged over locations, tended to express a wide range of their genetic variability for grain yield. Grain yield variations ranged from 2396 to $4063 \mathrm{~kg} / \mathrm{ha}$. Variety BH 546 out yielded which was followed by MH140. Local red was least with respect to grain yield performance. The significant difference among the genotypes showed variations in their response (yield potential) to different locations.

Location by variety interactions resulted in significant differences on ear height, cob length, seeds per row, biomass and grain yield (Table 1, $2 \& 3$ ). For aforementioned parameters, varieties had relatively superiority at Kindo Koyisha as compared to Humbo. In general the performance of varieties was poor at Humbo with the grain yield variability ranged from 2396 to $3021 \mathrm{~kg} / \mathrm{ha}$. At Humbo varieties MH140, MH130, BH546 and Melkasa IV gave relatively higher grain yield with HI (Physiological efficiency and ability of converting total dry matter into economic yield) values were $0.30,0.40,0.28$ and 0.36 , respectively. This variability might be attributed to varietal differences in maize genotypes in response to the prevailing environmental conditions. Hence, Humbo location could be considered as a stressful environment with profound limitation in potential performance of maize varieties. At Kindo Koyisha maize varieties expressed relatively better performance with respect to grain yield. Grain yield variability ranged from 2604 to $5208 \mathrm{~kg} / \mathrm{ha}$ from lowest to the highest. At this 
location varieties with superior performance with sounding grain yield were BH546, MH140, BH547 and MH130. This probably indicates that genotypes describe the complete set of genes inherited by an individual that is important for the expression of a trait under consideration in a particular environment. In general maize varieties at Kindo Koyisha performed best to their potential as compared to Humbo. Maize varieties BH546, MH130 and MH140 showed relatively stability across location with superiority of grain yield. Abay and Bjornstad (2009) indicated that genotype by environment ( $\mathrm{G} \times \mathrm{E})$ interactions is a differential genotypic expression across environments which affect the genotypes rankings within each environment and hence relevant for identifying mega environments and targeting genotypes. Moreover, the significant of $\mathrm{G} X \mathrm{E}$ indicates the presence of fluctuation of genotypes performance across environments or testing sites with inconsistency performance. Similar results were recorded by Akcura et al. (2005), Acura and Kaya (2008) Asfaw (2008) Dagne (2008) Solomon et al. (2008) Abdurhaman (2009) and Muluken (2009). The relationship between selected agronomic traits with grain is depicted in Table 5. The correlation coefficient ( $\mathrm{r}$ ) values of selected agronomic traits with grain yield ranged from -0.05 to 0.82 . Plant and ear height were positively significantly $(\mathrm{P} \leq 0.05)$ correlated which might suggest that the traits are closely associated with grain yield. Similarly, number seeds per row, seeds per cob, ear length, ear diameter, biomass and TSW had positively significantly associated with yield. In contrast, number of rows per cob with grain yield correlation was not significant. In general the correlation of almost all agronomic traits with grain yield was relatively strong indicating that their contribution towards grain yield was considerable.

\section{Conclusion}

Maize varieties reacted differently for agronomic traits measured in response to location with respect of their genetic variability. Generally almost all maize varieties exhibited superior performance at Kindo Koyisha than that of Humbo. Based on this result, varieties BH546, MH140 and MH130 could be used at both locations. Moreover, varieties BH546 and MH 140 at Kindo Koyisha whereas varieties MH 140, MH 130 and Melkasa IV at Humbo showed relatively better adaptation to their respective locations.

\section{References}

Aldrich, S.R., Scott, W.O. and Leng, E.R., 1978. Modern corn production. 2nd edition.A \& L Publications, Illinois.

CSA (Central Statistical Agency), 2010. Federal democratic republic of Ethiopia Crop Production Forecast Sample Survey, Statistical Bulletin. Addis Ababa.

FAO (Food and Agricultural Oorganization), 2003. Yearbook of maize production 177: 265, FAO, Rome, Italy.

Maredia, M., Byerlee, D. and Pee, P., 2000. Impacts of food crop improvement research: Evidence from SubSaharan Africa. Food Policy 25: 531-559.

Mosisa, W., Hadji, T., Mandefro, N. and Abera, D., 2002. Maize production trends and research in Ethiopia. In: N. Manderfo, D. Tanner \& S. Afriyie (eds.). Proceeding of the second National Maize Workshop of Ethiopia. 12-16 November 2001, Addis Ababa, Ethiopia.

Palwal, R.L., 2000. Introduction to maize and its importance: Tropical maize: Improvement and production. Pp 1-3. In: Plant production and protection series No. 28. FAO, Rome.

Pingali, P.L. \& Pandey, S., 2001. Meeting world maize needs: Technological opportunities and priorities for public sector. Pp 1-20. In: Pingali, P.L. (ed.). CIMMYT 1999-2000. World Maize Facts and Trends. CIMMYT, Mexico.

Stroosnijder, L., 2003. Technologies for improving rainfall use efficiency in semi-arid Africa. Pp 92-102. In: D. Beukes, M.de Villiers, S. Mkhize, H. Sally \& L. Van Rensburg (eds.). Proceeding of the Symposium and Workshop on water conservation technologies for sustainable dryland agriculture in sub-Saharan Africa, Bloemfontein, South Africa.

Vasal, S.K., 2000. The quality maize story. Food and Nutrtion Bulletin 12: 445. 
Table 1. Plant and ear heights as affected by location and varieties

\begin{tabular}{|c|c|c|c|}
\hline Location & Variety & Plant height & Ear height \\
\hline \multirow{11}{*}{ Kindo Koyisha } & BH546 & 291 & $124 b c$ \\
\hline & BH547 & 268 & $147 \mathrm{a}$ \\
\hline & Gibe II & 228 & $103 \mathrm{de}$ \\
\hline & MH130 & 204 & $82 \mathrm{fg}$ \\
\hline & Melkasa IV & 201 & $88 \mathrm{ef}$ \\
\hline & MH140 & 259 & $121 \mathrm{~cd}$ \\
\hline & Melkasa II & 217 & $88 \mathrm{ef}$ \\
\hline & Melkasa 6Q & 202 & $82 \mathrm{fg}$ \\
\hline & Local red & 244 & $141 \mathrm{ab}$ \\
\hline & Local mixed & 245 & $144 a$ \\
\hline & Local white & 255 & $148 \mathrm{a}$ \\
\hline \multirow{12}{*}{ Humbo } & BH546 & 178 & $72 \mathrm{f}-\mathrm{g}$ \\
\hline & BH547 & 189 & $86 \mathrm{ef}$ \\
\hline & Gibe II & 155 & 57hi \\
\hline & MH130 & 117 & $40 \mathrm{ij}$ \\
\hline & Melkasa IV & 135 & $54 \mathrm{hi}$ \\
\hline & MH140 & 150 & 58hi \\
\hline & Melkasa II & 136 & 54hi \\
\hline & Melkasa 6Q & 110 & $34 \mathrm{j}$ \\
\hline & Local red & 148 & $57 \mathrm{hi}$ \\
\hline & Local mixed & 153 & $65 \mathrm{gh}$ \\
\hline & Local white & 122 & $55 \mathrm{hi}$ \\
\hline & LSD & NS & 18 \\
\hline \multirow{12}{*}{ Variety mean } & BH546 & $235 a$ & $98 \mathrm{bc}$ \\
\hline & BH547 & $229 a$ & $117 \mathrm{a}$ \\
\hline & Gibe II & $191 b c$ & 80de \\
\hline & MH130 & $161 \mathrm{ef}$ & $61 f$ \\
\hline & Melkasa IV & $168 d-f$ & $71 \mathrm{ef}$ \\
\hline & MH140 & $205 b$ & $90 \mathrm{~cd}$ \\
\hline & Melkasa II & $177 \mathrm{c}-\mathrm{e}$ & $71 \mathrm{ef}$ \\
\hline & Melkasa 6Q & $156 f$ & $58 \mathrm{f}$ \\
\hline & Local red & $196 b c$ & $99 b c$ \\
\hline & Local mixed & $199 b$ & $105 \mathrm{ab}$ \\
\hline & Local white & $188 b-d$ & $101 b c$ \\
\hline & LSD & 21 & 13 \\
\hline \multirow{4}{*}{ Location mean } & Kindo Koyisha & $238 a$ & $115 \mathrm{a}$ \\
\hline & Humbo & $145 b$ & $58 b$ \\
\hline & LSD & 9 & 5 \\
\hline & CV (\%) & 9.2 & 13.3 \\
\hline
\end{tabular}

Means followed by the same letters within a column are not significantly different at $5 \%$ probability level, NS= not significant 
Table 2. Cob length and diameter as affected by location and varieties

\begin{tabular}{|c|c|c|c|}
\hline Location & Variety & $\begin{array}{l}\text { Cob length } \\
(\mathrm{cm})\end{array}$ & $\begin{array}{l}\text { Cob diameter } \\
(\mathrm{cm})\end{array}$ \\
\hline \multirow{11}{*}{ Kindo Koyisha } & BH546 & $15.83 \mathrm{a}$ & 4.37 \\
\hline & BH547 & $14.45 a-c$ & 4.79 \\
\hline & Gibe II & $12.71 \mathrm{c}-\mathrm{f}$ & 4.19 \\
\hline & MH130 & $13.09 \mathrm{c}-\mathrm{f}$ & 4.31 \\
\hline & Melkasa IV & $14.15 a-d$ & 4.26 \\
\hline & MH140 & $13.64 b-e$ & 4.39 \\
\hline & Melkasa II & $12.91 \mathrm{c}-\mathrm{f}$ & 4.03 \\
\hline & Melkasa 6Q & $11.97 \mathrm{ef}$ & 4.34 \\
\hline & Local red & $12.29 \mathrm{~d}-\mathrm{f}$ & 4.27 \\
\hline & Local mixed & $12.96 \mathrm{c}-\mathrm{f}$ & 4.45 \\
\hline & Local white & $12.10 \mathrm{ef}$ & 4.17 \\
\hline \multirow{12}{*}{ Humbo } & BH546 & $14.43 a-c$ & 4.32 \\
\hline & ВH547 & $13.03 c-f$ & 4.71 \\
\hline & Gibe II & $12.69 \mathrm{c}-\mathrm{f}$ & 4.33 \\
\hline & MH130 & $11.96 \mathrm{ef}$ & 3.95 \\
\hline & Melkasa IV & $12.24 \mathrm{ef}$ & 3.99 \\
\hline & MH140 & $12.77 \mathrm{c}-\mathrm{f}$ & 4.16 \\
\hline & Melkasa II & $11.89 \mathrm{ef}$ & 4.13 \\
\hline & Melkasa 6Q & $11.27 \mathrm{fg}$ & 4.19 \\
\hline & Local red & $12.66 \mathrm{c}-\mathrm{f}$ & 4.25 \\
\hline & Local mixed & $12.62 \mathrm{c}-\mathrm{f}$ & 4.25 \\
\hline & Local white & $9.69 \mathrm{~g}$ & 3.89 \\
\hline & LSD & 1.90 & NS \\
\hline \multirow{12}{*}{ Variety mean } & BH546 & $15.13 a$ & $4.75 \mathrm{a}$ \\
\hline & BH547 & $13.74 b$ & $4.34 b$ \\
\hline & Gibe II & $12.70 \mathrm{bc}$ & $4.26 b c$ \\
\hline & MH130 & $12.53 \mathrm{bc}$ & $4.13 b c$ \\
\hline & Melkasa IV & $13.19 b$ & $4.13 b c$ \\
\hline & MH140 & $13.20 \mathrm{~b}$ & $4.27 b c$ \\
\hline & Melkasa II & $12.40 \mathrm{bc}$ & $4.08 \mathrm{c}$ \\
\hline & Melkasa 6Q & $11.62 \mathrm{c}$ & $4.27 b c$ \\
\hline & Local red & $12.48 \mathrm{bc}$ & $4.26 b c$ \\
\hline & Local mixed & $12.79 \mathrm{bc}$ & $4.35 b$ \\
\hline & Local white & $12.39 b c$ & $4.03 c$ \\
\hline & LSD & 1.34 & 0.24 \\
\hline \multirow{4}{*}{ Location mean } & Kindo Koyisha & $13.55 \mathrm{a}$ & 4.32 \\
\hline & Humbo & $12.29 b$ & 4.19 \\
\hline & LSD & 0.57 & NS \\
\hline & CV (\%) & 8.9 & 4.9 \\
\hline
\end{tabular}

Means followed by the same letters within a column are not significantly different at 5\% probability level, $\mathrm{NS}=$ not significant 
Table 3. Number of rows per cob, seeds per row, seeds per cob and TSW as affected by location and varieties

\begin{tabular}{|c|c|c|c|c|c|}
\hline Location & Variety & $\begin{array}{l}\text { Rows } \\
\text { per ear }\end{array}$ & $\begin{array}{l}\text { Seeds } \\
\text { per row }\end{array}$ & $\begin{array}{l}\text { Seeds } \\
\text { per ear }\end{array}$ & $\begin{array}{l}\text { TSW } \\
\text { (g) }\end{array}$ \\
\hline \multirow{11}{*}{ Kindo Koyisha } & BH546 & 13.6 & $36 \mathrm{a}$ & 531 & 295 \\
\hline & BH547 & 14.8 & $34 \mathrm{ab}$ & 481 & 329 \\
\hline & Gibe II & 13.2 & $29 c-g$ & 387 & 281 \\
\hline & MH130 & 13.6 & $33 a-c$ & 402 & 311 \\
\hline & Melkasa IV & 13.6 & $31 b-e$ & 408 & 296 \\
\hline & MH140 & 14.8 & $30 b-f$ & 441 & 322 \\
\hline & Melkasa II & 13.3 & $30 b-e$ & 407 & 285 \\
\hline & Melkasa 6Q & 15.3 & $27 d-h$ & 444 & 278 \\
\hline & Local red & 13.8 & $26 e-h$ & 357 & 341 \\
\hline & Local mixed & 13.2 & $27 d-h$ & 373 & 356 \\
\hline & Local white & 12.8 & $29 c-f$ & 327 & 369 \\
\hline \multirow{12}{*}{ Humbo } & BH546 & 13.0 & $31 b-d$ & 407 & 376 \\
\hline & BH547 & 15.3 & $27 \mathrm{e}-\mathrm{h}$ & 410 & 347 \\
\hline & Gibe II & 14.3 & $27 \mathrm{e}-\mathrm{h}$ & 382 & 320 \\
\hline & MH130 & 13.0 & 24hi & 314 & 309 \\
\hline & Melkasa IV & 13.0 & $26 f-i$ & 334 & 344 \\
\hline & MH140 & 14.3 & $24 g-i$ & 348 & 368 \\
\hline & Melkasa II & 14.3 & $24 \mathrm{hi}$ & 339 & 315 \\
\hline & Melkasa 6Q & 14.3 & $26 f-i$ & 369 & 285 \\
\hline & Local red & 13.0 & $29 c-f$ & 374 & 315 \\
\hline & Local mixed & 12.7 & $28 d-g$ & 360 & 338 \\
\hline & Local white & 12.0 & $22 i^{\circ}$ & 262 & 332 \\
\hline & LSD & NS & 4 & NS & NS \\
\hline \multirow{12}{*}{ Variety mean } & BH546 & $13.3 \mathrm{c}-\mathrm{e}$ & $34 \mathrm{a}$ & $469 a$ & $336 a-c$ \\
\hline & BH547 & $15.1 \mathrm{a}$ & $30 b$ & $445 \mathrm{ab}$ & $338 \mathrm{ab}$ \\
\hline & Gibe II & $13.8 \mathrm{a}-\mathrm{e}$ & $28 b c$ & $384 c$ & $301 \mathrm{~cd}$ \\
\hline & MH130 & $13.3 \mathrm{c}-\mathrm{e}$ & $28 b c$ & $358 \mathrm{c}$ & $310 b-d$ \\
\hline & Melkasa IV & $13.3 \mathrm{c}-\mathrm{e}$ & $28 b c$ & $371 \mathrm{c}$ & $320 a-c$ \\
\hline & MH140 & $14.6 \mathrm{a}-\mathrm{c}$ & $27 b c$ & $394 b c$ & $345 \mathrm{ab}$ \\
\hline & Melkasa II & $13.8 \mathrm{a}-\mathrm{d}$ & $27 b c$ & $373 c$ & $299 \mathrm{~cd}$ \\
\hline & Melkasa 6Q & $14.8 \mathrm{ab}$ & $27 b c$ & $406 \mathrm{bc}$ & $282 d$ \\
\hline & Local red & $13.4 \mathrm{~b}-\mathrm{e}$ & $28 b c$ & $366 c$ & $328 \mathrm{a}-\mathrm{c}$ \\
\hline & Local mixed & $12.9 \mathrm{de}$ & $28 b c$ & $367 \mathrm{c}$ & $347 \mathrm{a}$ \\
\hline & Local white & $12.4 \mathrm{e}$ & $26 \mathrm{c}$ & $295 d$ & $351 \mathrm{a}$ \\
\hline & LSD & 1.4 & 3 & 53 & 36 \\
\hline \multirow{4}{*}{ Location mean } & Kindo Koyisha & 13.8 & $30 \mathrm{a}$ & $414 a$ & 314 \\
\hline & Humbo & 13.6 & $26 b$ & $355 b$ & 332 \\
\hline & LSD & NS & 1 & 22 & NS \\
\hline & CV (\%) & 8.8 & 9.2 & 12.0 & 9.7 \\
\hline
\end{tabular}

Means followed by the same letters within a column are not significantly different at 5\% probability level, NS$=$ not significant 
Table 4. Biomass, grain yield and harvest index as affected by location and varieties

\begin{tabular}{|c|c|c|c|c|}
\hline Location & Variety & $\begin{array}{l}\text { Biomass } \\
(\mathrm{kg} / \mathrm{ha})\end{array}$ & $\begin{array}{ll}\text { Grain } & \text { yield } \\
(\mathrm{kg} / \mathrm{ha}) & \\
\end{array}$ & HI \\
\hline \multirow{11}{*}{ Kindo Koyisha } & BH546 & $15938 \mathrm{ab}$ & $5208 \mathrm{a}$ & 0.28 \\
\hline & BH547 & $17188 \mathrm{a}$ & 4479ab & 0.26 \\
\hline & Gibe II & 10729b-e & $3438 \mathrm{a}-\mathrm{c}$ & 0.30 \\
\hline & MH130 & $10417 b-e$ & $3958 \mathrm{a}-\mathrm{c}$ & 0.35 \\
\hline & Melkasa IV & 8542 de & $2917 b c$ & 0.33 \\
\hline & MH140 & $14896 a-c$ & $5000 \mathrm{a}$ & 0.32 \\
\hline & Melkasa II & 8646 de & $2604 c$ & 0.27 \\
\hline & Melkasa 6Q & $6979 \mathrm{e}$ & $2708 b c$ & 0.38 \\
\hline & Local red & $9583 \mathrm{c}-\mathrm{e}$ & $2708 b c$ & 0.18 \\
\hline & Local mixed & $10729 b-e$ & $3021 b c$ & 0.24 \\
\hline & Local white & 10104b-e & $2917 b c$ & 0.14 \\
\hline \multirow{12}{*}{ Humbo } & BH546 & $13542 a-d$ & $2917 b c$ & 0.28 \\
\hline & BH547 & $12188 \mathrm{a}-\mathrm{e}$ & $2500 \mathrm{c}$ & 0.29 \\
\hline & Gibe II & $9375 c-e$ & $2604 b c$ & 0.33 \\
\hline & MH130 & $10104 b-e$ & $3021 b c$ & 0.30 \\
\hline & Melkasa IV & $9375 c-e$ & $2917 b c$ & 0.36 \\
\hline & MH140 & $9375 c-e$ & $3021 b c$ & 0.40 \\
\hline & Melkasa II & $10104 b-e$ & $2708 b c$ & 0.25 \\
\hline & Melkasa 6Q & $7292 \mathrm{e}$ & $2708 b c$ & 0.37 \\
\hline & Local red & $11458 a-e$ & $2396 \mathrm{c}$ & 0.38 \\
\hline & Local mixed & $11458 \mathrm{a}-\mathrm{e}$ & $2604 c$ & 0.34 \\
\hline & Local white & $7604 d e$ & $2396 c$ & 0.27 \\
\hline & LSD & 5943 & 1860 & NS \\
\hline \multirow{12}{*}{ Variety mean } & BH546 & $14792 \mathrm{a}$ & $4063 a$ & 0.28 \\
\hline & BH547 & $14688 \mathrm{ab}$ & $3438 a-c$ & 0.27 \\
\hline & Gibe II & $10104 \mathrm{~cd}$ & $3021 a-c$ & 0.32 \\
\hline & MH130 & $10208 \mathrm{~cd}$ & $2500 \mathrm{c}$ & 0.33 \\
\hline & Melkasa IV & $8958 \mathrm{~cd}$ & $2917 a-c$ & 0.35 \\
\hline & MH140 & $12188 \mathrm{a}-\mathrm{c}$ & $3958 \mathrm{ab}$ & 0.36 \\
\hline & Melkasa II & $9375 \mathrm{~cd}$ & $2604 c$ & 0.27 \\
\hline & Melkasa 6Q & $7083 d$ & $2706 \mathrm{bc}$ & 0.38 \\
\hline & Local red & $10521 \mathrm{~b}-\mathrm{d}$ & $2396 c$ & 0.28 \\
\hline & Local mixed & $11146 a-d$ & $2813 a-c$ & 0.29 \\
\hline & Local white & $8854 \mathrm{~cd}$ & $2604 c$ & 0.20 \\
\hline & LSD & 4202 & 1316 & NS \\
\hline \multirow{4}{*}{ Location mean } & Kindo Koyisha & 11250 & $3438 \mathrm{a}$ & 0.28 \\
\hline & Humbo & 10208 & $2708 b$ & 0.33 \\
\hline & LSD & NS & 673 & NS \\
\hline & $\mathrm{CV}(\%)$ & 13.6 & 1.3 .2 & 32.4 \\
\hline
\end{tabular}

Means followed by the same letters within a column are not significantly different at 5\% probability level, $\mathrm{NS}=$ not significant

Table 5. Correlation of growth and yield components with grain yield

\begin{tabular}{ll}
\hline Parameter & Grain yield \\
\hline Plant height & $0.82^{*}$ \\
Ear height & $0.68^{*}$ \\
Number of rows per cob & $-0.05^{\mathrm{NS}}$ \\
Number of seeds per row & $0.72^{*}$ \\
Number of seeds per cob & $0.60^{*}$ \\
Ear length & $0.72^{*}$ \\
Ear diameter & $0.56^{*}$ \\
Biomass & $0.78^{*}$ \\
Thousand seed weight & $0.77^{*}$ \\
\hline
\end{tabular}

